(= Tandjour, Mdo, xviii, foll. 44-299)," and the statement "Deest in Tibetan" must be erased.

As concerns Nìlacakșus $=\bar{A}$ ryadeva $=$ Pingalanetra, I have nothing to say, except that the commentary in Nanjio 1179 is identical neither with Nāgārjuna's, nor with Buddhapālita's, nor with Candrakirtī's commentaries on the same book. "A chaque jour suffit sa peine."-Yours faithfully,

L. de la Vallée Poussin.

\title{
8. The Brahmajāla Suttanta in Chinese.
}

Dear Professor Rhys Davids,-Referring to my note “Pāli and Sanskrit" (J.R.A.S., 1903, p. 359), Dr. K. Watanebe writes as follows:- "No. 1087 in Nanjio's Cat. is entirely different from No. 554. The former, as you mentioned, belongs to the Mahāyāna class ; while the latter is classified as Small Vehicle Sūtra (see Nanjio), and it corresponds with slight differences to the Pâli Brahmajālasutta. There is another Chinese version of this sutta contained in the Chinese Dighanikāya (Nanjio, 545)."Yours faithfully,

L. de la Vallée Poussin.

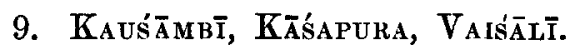

Jaunpur.
May 7 th, 1903.

Dear Professor Rhys Davids, - I have good reasons, which I intend to publish in due course, for believing that the city of Kausanambī visited by Yuan Chwang should be identified with Gürgi (Arch. Surv. Rep., xix, pl. xx ; xxi, pl. xxxvi); that Kăśapura, visited by the same pilgrim, is now known as Jhūsī (Mon. Antiq. N.W.P., 138); and that Vaiśali city was situated in the Chaparā District of Bengal, and is represented by the extensive remains of the undescribed walled city at Mānjhi, on the left bank of the Ghāgharā (Gogrā) river, opposite to the confluence of this river with the old bed of the Ganges.-Yours truly,

W. Vost. 